\title{
EFEK PERLAKUAN PENDAHULUAN TERHADAP KANDUNGAN NUTRISI MAKRO RENDANG BELUT
}

\section{The Effect of Pre Treatment to The Macro Nutrient Content of Eel Rendang}

\section{Failisnur* dan Silfia}

Balai Riset dan Standardisasi Industri Padang

JI. Raya LIK Ulu Gadut No. 23 Telp. (0751) 72201 Fax.(0751)71320 Padang 25164

*e-mail: failis@yahoo.co.id

Diterima : 12 Maret 2012, Revisi akhir: 22 Mei 2012

\begin{abstract}
ABSTRAK
Belut (Monopterus albus Zuieuw) merupakan bahan pangan hewani yang banyak digemari karena rasanya cukup enak, potensi dan penyebaran merata, kandungan gizi tinggi dan juga berkhasiat obat. Pengolahan belut menjadi rendang belut dapat menjadi alternatif dalam meningkatkan penerimaan konsumen dan memberikan pilihan berarti bagi penikmat makanan dari belut. Penelitian dilakukan dengan berbagai perlakuan pendahuluan terhadap bahan baku belut berupa belut segar, belut yang dibakar dan belut yang digoreng sebelum dilakukan proses perendangan, kemudian dianalisis kandungan nutrisinya yang meliputi kadar air, protein, lemak dan organoleptik serta ketahanan simpannya meliputi kadar air, bilangan peroksida dan organoleptik secara visual. Hasil penelitian menunjukkan bahwa perlakuan terbaik adalah penggunaan belut yang dibakar terlebih dahulu sebelum dilakukan proses perendangan dimana dari hasil uji organoleptik lebih disukai panelis dengan nilai skala hedonik 4,7; 4,8 dan 4,3 berturut-turut untuk rasa, tekstur, dan aroma. Dari hasil uji kimia didapatkan kadar air dan lemak yang rendah yaitu $9,93 \%$ dan $24,42 \%$, kadar protein yang lebih tinggi yaitu $32,02 \%$. Produk masih tahan sampai 3 bulan penyimpanan dengan kadar air setelah 3 bulan $16,2 \%$ dan bilangan peroksida 9,2 serta rasa, aroma dan tekstur masih baik.
\end{abstract}

Kata Kunci: Belut, perlakuan pendahuluan, dibakar, digoreng, rendang belut

\begin{abstract}
Eel (Monopterus albus Zuieuw) is a much prefered food because the taste is good, and the potential spread evenly, high nutrient content and medicinal. Product of eel rendang can be an alternative to increase consumer acceptance and provide meaningful choices for food lovers of the eel. Research conducted with a variety of pre-treatment of raw materials in the form of fresh eel, baked and fried eel before the cooking of rendang, and then analyzed the nutritional content that includes water content, proteins, fats, organoleptic and resistance storage consisted of moisture content, peroxide number and organoleptic visually. Research results showed that the best treatment was the use of baked eel first before cooking process as the preferred flavor, texture, and aroma with the score were 4,7; 4,8 and 4,3 respectively. The chemical testing showed low content of fat and water that was $9.93 \%$ and $24.42 \%$ respectively and high protein content that was $32,02 \%$. The product still resistant until 3 months of storage with water content $16,2 \%$ and peroxide number 9,2 as well as flavor, aroma and texture were still good.
\end{abstract}

Key words: Eel, pre treatment, burned, fried, eel rendang 


\section{PENDAHULUAN}

Belut dikenal sebagai salah satu bahan makanan yang mengandung banyak unsur gizi yaitu protein (18,4\%), kalori (303 kkal), lemak (27 g), zat besi $(2,0 \mathrm{mg})$, kalsium (20 $\mathrm{mg})$, serta vitamin A (1600 SI), B (0,1 mg), dan $C(2 \mathrm{mg})$. Tingginya gizi yang terkandung pada belut, menjadikan belut banyak diminati oleh masyarakat bahkan sampai ke luar negeri. Disamping itu, kandungan fosfor, vitamin $\mathrm{A}$ dan $\mathrm{C}$ belut lebih tinggi bila dibandingkan dengan daging sapi dan telur (Ruslan, 2007).

Belut sangat bermanfaat bagi kesehatan tubuh diantaranya meningkat-kan vitalitas, sistim kekebalan tubuh, ketajaman penglihatan, kecerdasan dan daya ingat, mencegah anemia, osteophorosis, jantung koroner, darah tinggi, hepatitis, menormalkan tekanan darah, rematik dan kanker (Nur, 2008; Anonim, 2010). Disamping itu nilai cerna protein sangat tinggi sehingga dapat menjadi asupan gizi berbagai tingkat usia.

Belut mempunyai bentuk yang licin memanjang mirip dengan ular yang menimbulkan perasaan jijik bila melihatnya. Disamping itu kandungan lemak belut yang tinggi dikhawatirkan berefek kurang baik bagi kesehatan sehingga menjadi kendala yang cukup berarti bagi konsumen dalam mengkonsumsinya dan menyebabkan belut kurang begitu populer untuk dikonsumsi (Sundoro, 2002). Adanya upaya pengolahan belut diharapkan dapat meningkatkan pendayagunaan dan tingkat penerimaan konsumen terhadap belut.

Pengolahan belut, seperti halnya pengolahan daging lain bertujuan untuk memperpanjang masa simpan, memperbaiki sifat organoleptik, menambah variasi bentuk olahan dan memungkinkan tersedianya produk olahan daging setiap saat. (Pane, 2006). Salah satu olahan belut yang bergizi tinggi, enak, dan mempunyai prospek pasar yang cukup baik serta lebih tahan lama dalam penyimpanan adalah rendang belut.

Rendang adalah makanan tradisional yang terbuat dari daging sapi, daging lainnya sebagai bahan utama dengan ditambahkan santan kelapa dan bahan lain seperti cabe, lengkuas, bawang, dan bumbu lainnya, tanpa bahan pengawet buatan. Rendang belut mempunyai rasa yang enak dan khas, dapat dijadikan oleh-oleh untuk lauk pauk pendamping nasi atau sebagai bekal bagi dalam perjalanan jauh dan memakan waktu yang cukup lama karena ketahanan simpannya yang tinggi. Jika rutin dipanaskan, kelezatan rasa rendang semakin terasa. Kelezatan rendang berasal dari cara memasaknya, waktu proses yang cukup lama, pemilihan bahan-bahan dan waktu yang tepat untuk memasukkan dagingnya (Adhytia, 2011).

Pada pembuatan rendang belut skala rumah tangga, beberapa metoda yang pernah dilakukan pada bahan baku belut sebelum dilakukan proses perendangan diantaranya adalah dengan menggunakan belut segar lansung direndang, membakar belut atau dengan menggoreng belut terlebih dahulu baru direndang. Menurut Astawan (2008), pembakaran pada belut sebelum direndang dapat mengurangi kadar lemak pada belut karena lemak dalam jumlah berlebihan dalam produk olahan belut kurang dikehendaki.

Untuk itu perlu dilakukan penelitian efek perlakuan pendahuluan pada bahan baku belut sebelum dilakukan proses perendangan. Tujuan penelitian adalah untuk mendapatkan rendang belut dengan bentuk produk yang berbeda dengan bentuk asalnya, mempunyai kandungan nutrisi makro berguna yang dapat dipertahankan serta kandungan lemak belut dapat dikurangi, dan tahan disimpan dalam waktu yang lama.

\section{METODOLOGI PENELITIAN}

\section{Bahan}

Bahan utama yang digunakan dalam pembuatan rendang belut adalah belut segar. Belut dipilih ukuran yang agak besar ( \pm 125 g/ekor) agar dagingnya lebih legit. Bahan pembantu adalah sebagai berikut; belut segar, cabe, kelapa, garam, minyak goreng, bumbu-bumbu (bawang putih, bawang merah, jahe, lengkuas), daun jeruk, daun salam, sereh, dan kemasan serta bahan kimia untuk pengujian.

\section{Alat}

Peralatan yang digunakan antara lain; pisau, waskom, wajan, serokan, peniris 
minyak, sealer, kompor, talenan dan sebagainya serta peralatan untuk pengujian.

\section{Metoda Penelitian}

Dalam pembuatan rendang belut dilakukan variasi perlakuan pendahuluan pada bahan baku belut untuk dijadikan rendang sebagai berikut:

$A=$ Belut segar

$B=$ Belut yang dibakar

$\mathrm{C}=$ Belut yang digoreng

\section{Pelaksanaan Penelitian}

Belut dibersihkan dan dibakar di atas bara api sampai keluar minyaknya. Santan dimasak bersama cabe dan bumbu yang sudah dihaluskan dan daun-daun rempah sampai berminyak sambil diaduk terus agar santannya tidak pecah. Belut yang sudah dibakar dimasukkan ke dalam santan dan dimasak sambil sesekali diaduk dengan api kecil sampai agak mengering dan berwarna coklat sampai kehitaman. Diagram alir pembuatan rendang belut adalah seperti Gambar 1.

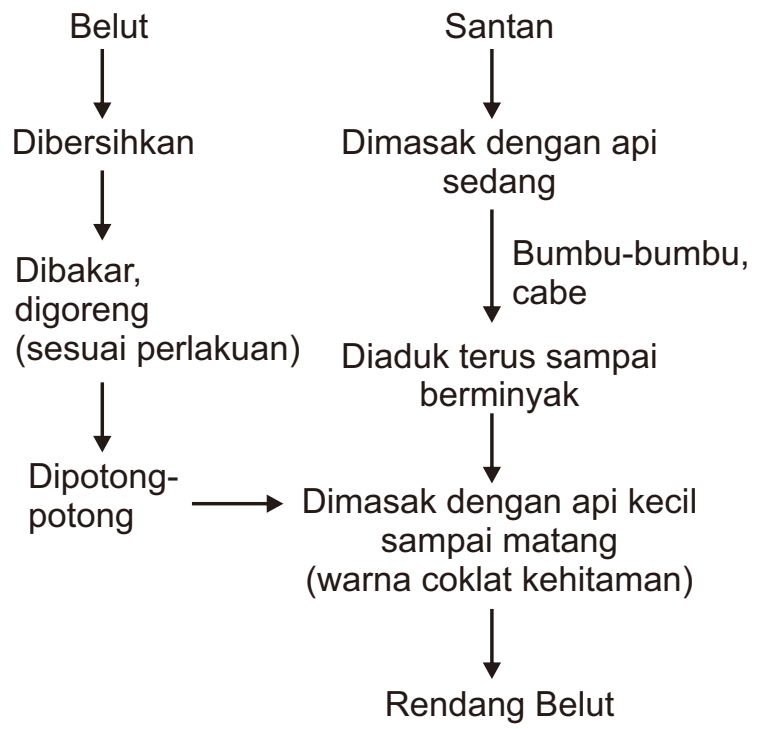

Gambar 1 . Diagram alir pembuatan
rendang belut.

\section{Analisis dan Pengamatan}

Analisis yang dilakukan terhadap rendang belut berupa kadar air menggunakan metoda oven, kadar protein dengan metoda Kjedahl dan kadar lemak dengan menggunakan metoda Weibull serta organoleptik rasa, tekstur dan aroma. Untuk uji organoleptik terhadap 15 orang panelis menggunakan skala hedonik sebagai berikut:

$5=$ Sangat suka
$4=$ Suka
$3=$ Cukup suka
$2=$ Kurang suka
$1=$ Tidak suka

\section{Pengamatan Penyimpanan}

Pengamatan penyimpanan meliputi kadar air dan bilangan peroksida pada bulan 1, 2 dan 3 serta organoleptik rasa, tekstur dan aroma secara visual.

\section{HASIL DAN PEMBAHASAN}

\section{Kadar Air, Protein dan Lemak}

Hasil analisis kadar air, protein dan lemak dari rendang belut adalah seperti pada Gambar 2.

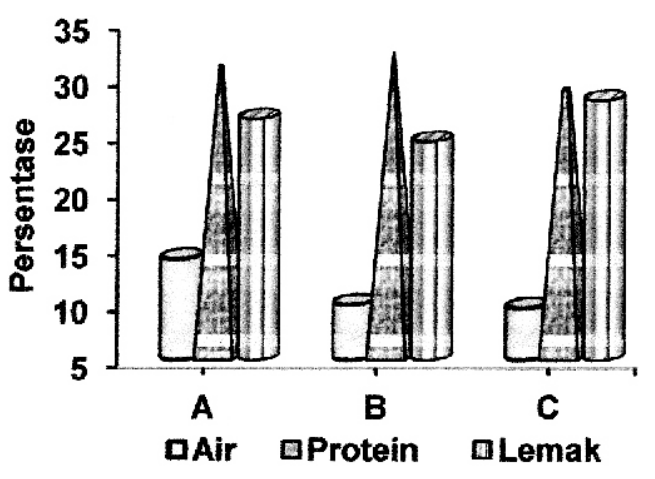

Gambar 2. Hasil Analisis kadar air, protein dan lemak rendang belut

Kadar air rendang belut tertinggi diperoleh pada perlakuan penggunaan belut segar (A) yaitu $14,01 \%$ dan terendah pada belut yang digoreng (C) $9,62 \%$. Hal ini dikarenakan belut segar masih mengandung kadar air yang cukup tinggi (58\%), sedangkan belut yang telah digoreng kadar 
airnya tinggal $6.20 \%$ (Failisnur, 2011). Pada saat penggorengan, minyak yang diserap untuk mengempukkan daging, sesuai dengan jumlah air yang menguap pada saat menggoreng sehingga semakin tinggi suhu dan lama penggorengan menyebabkan jumlah minyak yang terserap semakin banyak dan air yang menguap juga semakin banyak sehingga kadar air tertinggal pada bahan semakin rendah (Sartika, 2009).

Menurut Sutarsi (2009), selama penggorengan terjadi kenaikan suhu bahan dan penurunan kadar air secara simultan. Pada awal penggorengan energi yang diterima oleh bahan digunakan untuk menaikkan suhu bahan sampai mencapai titik didih air dalam bahan, tahap berikutnya suhu bahan cenderung stabil. Fenomena ini terjadi karena proses penguapan sebahagian besar air bahan dan energi panas yang diterima bahan digunakan untuk merubah fase air bahan dari cair menjadi gas sehingga sebahagian besar air teruapkan dan kadar air bahan menjadi turun.

Kadar protein rendang belut tertinggi diperoleh pada perlakuan penggunaan belut yang dibakar (B) yaitu $32,02 \%$ dan terendah pada perlakuan penggunaan belut yang digoreng (C) $28,76 \%$. Proses pembakaran cenderung lebih menurunkan kadar air dan lemak dari belut. Penggorengan bahan pangan pada suhu biasa $\left(163-196^{\circ} \mathrm{C}\right)$ dapat meningkatkan daya cerna protein tanpa menghasilkan senyawa toksik dan menginaktivasi beberapa enzim seperti protease, lipase, lipoksigenase, amilase, polifenoloksidase, enzim oksidatif dan hidrolitik lainnya sehingga umur simpan produk lebih lama.

Kadar lemak dari rendang belut yang dihasilkan cukup tinggi yaitu berkisar antara $28,76-32,02 \%$. Kadar lemak rendang belut tertinggi diperoleh pada perlakuan belut yang digoreng terlebih dahulu (C) yaitu $28,1 \%$ sedangkan terendah pada belut yang dibakar (B) $24,42 \%$. Pembakaran pada belut sebelum direndang bertujuan untuk mengurangi kadar lemak pada belut karena lemak dalam jumlah berlebihan dalam produk olahan belut kurang dikehendaki. Saat pembakaran terjadi, minyak yang ada pada belut keluar dari tubuh belut dan menetes ke kayu atau bara pembakar (Astawan, 2008).
Menurut Adawyah ( 2007), sebaiknya belut tidak diolah dengan cara digoreng, agar kadar lemaknya tidak bertambah banyak. Selama penggorengan bahan pangan dapat terjadi perubahan-perubahan fisikokimiawi baik pada bahan pangan yang digoreng, maupun minyak gorengnya. Apabila suhu penggorengannya lebih tinggi dari suhu normal $\left(168-196^{\circ} \mathrm{C}\right)$ maka akan menyebabkan degradasi minyak goreng berlangsung dengan cepat (antara lain titik asap menurun). Titik asap minyak goreng tergantung pada kadar gliserol bebas. Titik asap adalah saat terbentuknya akrolein yang tidak diinginkan dan dapat menimbulkan rasa gatal pada tenggorokan.

\section{Uji Organoleptik Rasa, Tekstur dan Aroma}

Dari penelitian yang dilakukan terhadap rendang belut didapatkan hasil seperti Gambar 3.

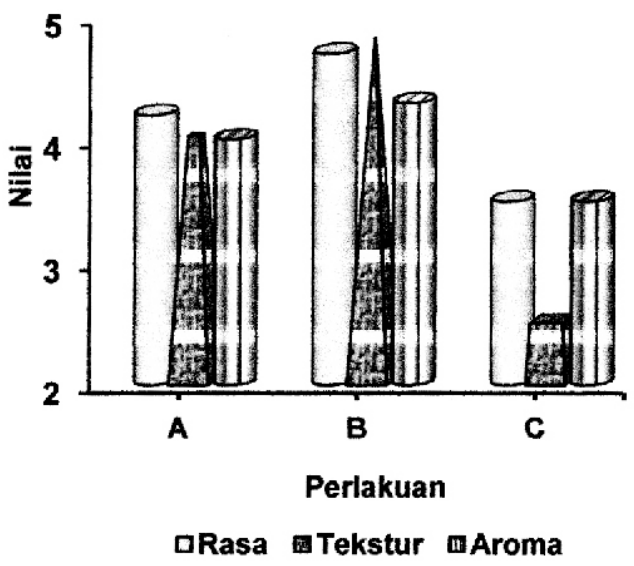

Gambar 3. Hasil pengamatan organoleptik pada rendang belut

Dari Gambar 3 terlihat bahwa untuk semua parameter organoleptik baik rasa, tekstur dan warna dari rendang belut yang paling disukai adalah perlakuan belut yang dibakar terlebih dahulu sebelum dilakukan proses perendangan (B) dibandingkan dengan penggunaan belut segar $(A)$ dan belut yang digoreng $(C)$. Penggunaan belut yang digoreng menyebabkan tekstur rendang lebih keras dan liat sedangkan belut 
segar (A) menghasilkan rendang belut sedikit lebih lunak karena kandungan airnya lebih tinggi.

Proses pembakaran belut ternyata memberikan rasa yang lebih enak dibandingkan apabila belut digoreng maupun belut segar. Hal ini disebabkan karena pada pembakaran akan dihasilkan juga asap yang mengandung senyawa fenol dan formaldehid yang memberikan rasa, tekstur dan aroma yang khas sekaligus berfungsi sebagai pengawet terhadap produk (Murniyati, 2000). Pembakaran pada produk daging menyebabkan lemak dalam daging akan mencair sehingga menambah palatabilitas (kelezatan) daging tersebut karena pecahnya komponen-komponen lemak menjadi produksi volatil seperti aldehid, keton, alkohol, asam, dan hidrokarbon yang sangat berpengaruh terhadap pembentukan flavor.

Pemasakan daging dengan suhu melebihi $70^{\circ} \mathrm{C}$ mengintensifkan rasa daging dan akan terjadi perubahan rasa seperti rasa darah atau serum daging segar yang dimasak menjadi lebih umami (gurih) rasa dan aromanya. Pengolahan dengan panas akan meningkatkan organoleptik rasa, daging lebih empuk dan gurih, warna lebih gelap karena terjadi dehidrasi air sehingga dapat meningkatkan tingkat penerimaan konsumen terhadap produk (Palupi, 2007). Peningkatan kualitas rasa dari produk olahan belut juga disebabkan oleh kandungan asam glutamat pada belut. Tingginya kadar asam glutamat pada produk pangan menjadikan produk tersebut berasa enak dan gurih (Astawan, 2008).

\section{Pengamatan Penyimpanan}

\section{Kadar Air}

Hasil analisis kadar air rendang belut selama 3 bulan penyimpanan adalah seperti pada Gambar 4. Dari rata-rata semua perlakuan terjadi peningkatan kadar air sampai 3 bulan penyimpanan. Penggunaan belut segar (A) menghasilkan kadar air yang lebih tinggi dibandingkan perlakuan lainnya, karena belut segar yang digunakan untuk proses perendangan mempunyai kadar air yang lebih tinggi $(58 \%)$ dibandingkan belut yang dibakar $(22,3 \%)$ maupun digoreng $(6,2 \%)$ terlebih dahulu (Failisnur, 2011).

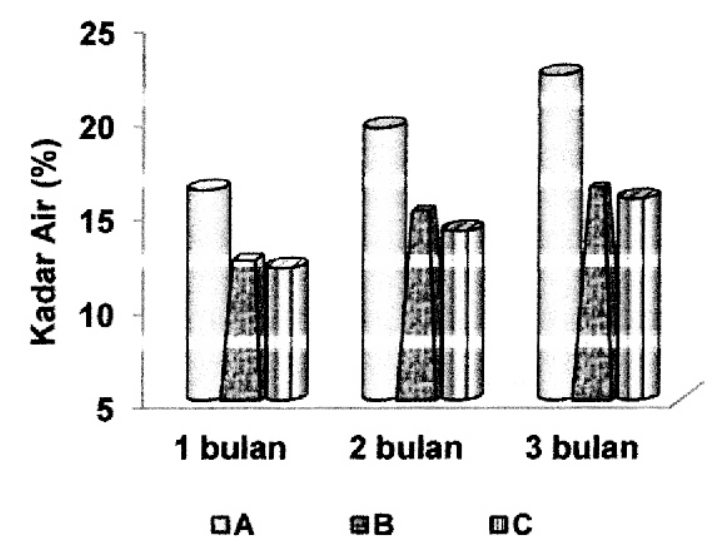

Gambar 4. Hasil analisis kadar air rendang belut selama 3 bulan penyimpanan.

Peningkatan kadar air setelah penyimpanan 3 bulan disebabkan karena terjadinya penyerapan uap air dari lingkungan ke dalam produk melalui bahan kemasan. Produk yang disimpan dengan pengemasan yang kurang sempurna akan berusaha menyesuaikan diri pada kondisi lingkungan yang seimbang, sehingga bila kelembaban ruang penyimpanan tinggi maka uap air yang ada dalam ruangan merembes melalui kemasan menuju ke dalam produk yang dapat meningkatkan kadar air produk. Menurut Pujiastuti (2005), penggunaan kemasan yang kedap air dan udara dapat mengurangi laju penyerapan uap air ke dalam bahan sehingga peningkatan kadar air pada bahan dapat ditekan seminimal mungkin dan umur simpan bahan menjadi lebih lama.

\section{Bilangan Peroksida}

Mutu dari suatu minyak dapat diketahui dari rasa dan aromanya. Salah satunya adalah ketengikan atau adanya peroksida akibat pengaruh suhu dan lama proses pemasakan serta penyimpanan dari minyak tersebut. Peroksida merupakan suatu tanda adanya pemecahan atau kerusakan pada minvak karena terjadi oksidasi (kontak dengan udara) yang menyebabkan bau dan aroma tengik pada minyak. Ukuran dari ketengikan dapat diketahui dengan 
menentukan bilangan peroksida dimana semakin tinggi bilangan peroksida maka semakin tinggi pula tingkat ketengikan suatu minyak.

Hasil analisis bilangan peroksida rendang belut selama 3 bulan penyimpanan dapat dilihat pada Gambar 5. Dari data terlihat bahwa bilangan peroksida dari rendang belut yang dihasilkan dari berbagai perlakuan terlihat sebanding dengan kadar lemak yang dikandung oleh produk rendang tersebut. Semakin tinggi kadar lemak dari rendang maka semakin banyak molekul lemak/minyak yang mungkin terurai sehingga bilangan peroksida yang dihasilkan juga semakin tinggi (Novelina, 1997). Perlakuan pendahuluan pada belut sebelum direndang melalui proses pembakaran (B), dapat mengurangi kadar lemak dari rendang sehingga bilangan peroksidanya juga lebih rendah yaitu 9,2 setelah 3 bulan penyimpanan. Menurut Standar Nasional Indonesia (SNI) 01-2902-1992 tentang Minyak Kelapa, kadar bilangan peroksida maksimal adalah 5,0 . Dari hasil penelitian yang dilakukan Prasetyawan (2011), bilangan peroksida pada minyak goreng baru yang digunakan oleh penjual gorengan di sekitar Universitas Jember rata-rata berkisar antara 8,477 sampai 11,431 sedangkan pada minyak goreng bekas antara 19,209 sampai 29,736 .

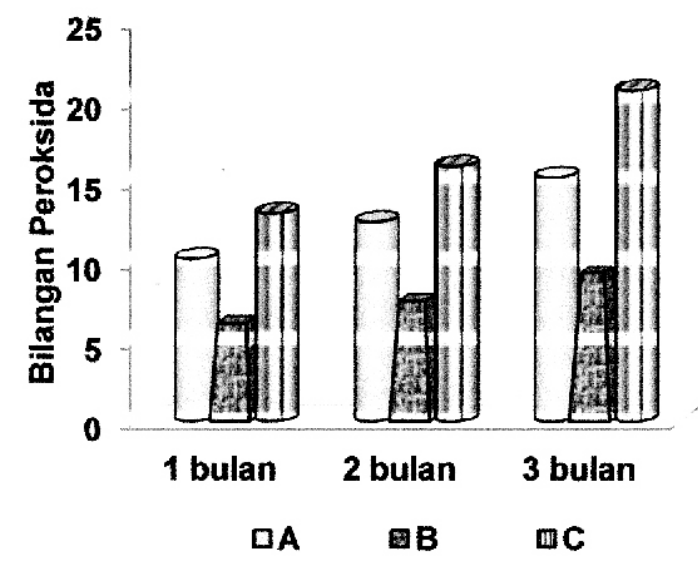

Gambar 5. Hasil analisis bilangan peroksida rendang belut selama 3 bulan penyimpanan.
Untuk semua perlakuan sampai 3 bulan penyimpanan, pada umumnya masih baik kecuali perlakuan penggorengan sebelum perendangan $(C)$ setelah 3 bulan simpan nilai bilangan peroksidanya naik cukup tinggi yaitu 20,7. Pada proses penggorengan belut, pemanasan minyak yang secara terus menerus pada suhu tinggi $\left(160-180^{\circ} \mathrm{C}\right)$ serta terjadinya kontak dengan oksigen dari udara luar, memudahkan terjadinya reaksi oksidasi pada minyak. Umumnya kerusakan oksidasi terjadi pada asam lemak tak jenuh (memiliki ikatan rangkap), tetapi bila minyak dipanaskan suhu $100^{\circ} \mathrm{C}$ atau lebih, asam lemak jenuhpun dapat teroksidasi. Proses menggoreng pada suhu $200^{\circ} \mathrm{C}$ lebih memudahkan kerusakan berupa reaksi oksidasi terutama pada minyak dengan derajat ketidakjenuhan tinggi. Ketaren (1989), menyebutkan bahwa kerusakan minyak diakibatkan oleh proses penggorengan pada suhu tinggi $\left(200-250^{\circ} \mathrm{C}\right)$.

Suhu pemanasan berpengaruh terhadap kerusakan lemak, makin tinggi suhu yang digunakan, maka kerusakan lemak akan semakin intens. Pada proses pemanggangan belut yang digunakan adalah bara api dengan suhu yang cukup rendah (90$110^{\circ} \mathrm{C}$ ) sehingga kerusakan lemak dapat diminimalisasi. Pada pemanggangan yang ekstrim, asam linoleat dan juga asam lemak lainnya akan dikonversi menjadi hidroperoksida yang tidak stabil oleh adanya aktivitas enzim lipoksigenase. Perubahan tersebut akan berpengaruh pada nilai gizi lemak dan vitamin (oksidasi vitamin larut lemak) (Palupi, 2007).

\section{Organoleptik Penyimpanan}

Pengamatan organoleptik rendang belut selama penyimpanan 3 bulan terhadap rasa, tekstur, warna dan aroma adalah seperti pada Tabel 1. Ketahanan rendang belut sampai 2 bulan penyimpanan pada umumnya masih baik, kecuali tekstur untuk perlakuan belut yang digoreng terlebih dahulu sudah kurang baik. Sedangkan untuk perlakuan belut yang dibakar, umur simpannya sampai 3 bulan masih cukup baik ditinjau dari organoleptik rasa, tekstur, warna dan aroma. 
Proses pemasakan rendang belut yang cukup lama (3-4 jam) menyebabkan penurunan kadar air yang signifikan sehingga dihasilkan produk rendang belut yang lebih tahan dalam penyimpanan. Menurut Palupi (2007), proses pemanasan menjadikan makanan lebih awet, tekstur, aroma dan rasa lebih baik serta daya cerna meningkat. Disamping itu pengaruh proses pembakaran menghasilkan asap yang mengandung senyawa fenol yang dapat berfungsi sebagai antioksidan. Senyawa fenol masuk ke permukaan bahan yang diasap, bahan tersebut menyebabkan ketahanan simpan yang lebih lama dan menghambat ketengikan (Sutaryo, 2004).

Tabel 1. Hasil pengamatan organoleptik rasa, tekstur, warna dan aroma rendang belut selama 3 bulan penyimpanan

\begin{tabular}{|c|c|c|c|c|}
\hline \multirow{2}{*}{ Parameter } & \multirow{2}{*}{ Perlakuan } & \multicolumn{3}{|c|}{ Bulan } \\
\cline { 2 - 5 } & & $\mathbf{1}$ & $\mathbf{2}$ & $\mathbf{3}$ \\
\hline \multirow{3}{*}{ Rasa } & $\mathrm{A}$ & $\mathrm{B}$ & $\mathrm{B}$ & $\mathrm{KB}$ \\
\cline { 2 - 5 } & $\mathrm{B}$ & $\mathrm{B}$ & $\mathrm{B}$ & $\mathrm{B}$ \\
\cline { 2 - 5 } & $\mathrm{C}$ & $\mathrm{B}$ & $\mathrm{B}$ & $\mathrm{KB}$ \\
\hline \multirow{3}{*}{ Tekstur } & $\mathrm{A}$ & $\mathrm{B}$ & $\mathrm{B}$ & $\mathrm{KB}$ \\
\cline { 2 - 5 } & $\mathrm{B}$ & $\mathrm{B}$ & $\mathrm{B}$ & $\mathrm{B}$ \\
\cline { 2 - 5 } & $\mathrm{C}$ & $\mathrm{B}$ & $\mathrm{KB}$ & $\mathrm{TB}$ \\
\hline \multirow{3}{*}{ Warna } & $\mathrm{A}$ & $\mathrm{B}$ & $\mathrm{B}$ & $\mathrm{B}$ \\
\cline { 2 - 5 } & $\mathrm{B}$ & $\mathrm{B}$ & $\mathrm{B}$ & $\mathrm{B}$ \\
\hline \multirow{3}{*}{ Aroma } & $\mathrm{C}$ & $\mathrm{B}$ & $\mathrm{B}$ & $\mathrm{B}$ \\
\hline & $\mathrm{A}$ & $\mathrm{B}$ & $\mathrm{B}$ & $\mathrm{KB}$ \\
\hline & $\mathrm{B}$ & $\mathrm{B}$ & $\mathrm{B}$ & $\mathrm{B}$ \\
\hline & $\mathrm{C}$ & $\mathrm{B}$ & $\mathrm{B}$ & $\mathrm{KB}$ \\
\hline
\end{tabular}

Keterangan; B (baik), KB (kurang baik), dan TB (tidak baik).

\section{KESIMPULAN DAN SARAN}

\section{Kesimpulan}

Dari hasil penelitian efek perlakuan pendahuluan terhadap kandungan nutrisi rendang belut dapat disimpulkan sebagai berikut :

1. Perlakuan pendahuluan pada belut berupa belut segar (A), belut yang dibakar (B) dan belut yang digoreng (C) memberikan pengaruh yang berbeda nyata terhadap kadar air, protein, lemak dan organoleptik rasa, tekstur, dan aroma rendang belut yang dihasilkan.
2. Perlakuan terbaik diperoleh pada belut yang dibakar (B) sebelum direndang, karena lebih disukai baik rasa, tekstur, dan aroma dengan nilai masingmasingnya adalah 4,7; 4,8 dan 4,3 dengan kadar air dan lemak yang rendah yaitu $9,93 \%$ dan $24,42 \%$, kadar protein yang lebih tinggi yaitu $32,02 \%$, serta produk masih tahan sampai 3 bulan penyimpanan dengan kadar air setelah 3 bulan 16,2\% dan bilangan peroksida 9,2 serta rasa, aroma dan tekstur masih baik.

\section{Saran}

Dari penelitian ini disarankan untuk dilakukan penelitian lanjutan dalam rangka diversifikasi produk olahan yang lain dari belut sehingga ketersediaan produk olahan belut bagi penikmat komoditi ini dapat terjaga.

\section{DAFTAR PUSTAKA}

Adawyah, R. 2007. Pengolahan dan Pengawetan Ikan. Bumi Aksara. Jakarta.

Adhytia, B. 2011. Rendang Makanan Terlezat di Dunia. VIVAnews.com

Anonim. 2010. Keunggulan Belut, Http://ratubelut.com. Diakses 28 November 2010

Astawan, M. 2008. Silicin Belut Kuatkan Tulang. http://kompas.com/read/xml /2008/11/07/10453394. Diakses 6 September 2011.

Dewan Standardisasi Nasional. 1992. Minyak Kelapa. Standar Nasional Indonesia (SNI) 01-2902-1992. BSN

Failisnur, Silfia, \& Marlusi. 2011. Diversifikasi Produk Olahan dari Belut. Komunikasi Penelitian Baristand Padang No. 292, BPKIMI Kemenperin RI.

Ketaren, S. 1986. Pengantar Teknologi Minyak dan Lemak Pangan. Jakarta. Penerbit Universitas Indonesia.

Murniyati, A., \& Sunarman. 2000. Pendinginan Pembekuan dan Pengawetan Ikan. Kanisius, Jogyakarta. 
Novelina \& Hamzah, N. 1997. Studi Mengenai Citarasa Rendang Yang Diawetkan dengan Cara Sterilisasi dan Pemberian Anti Oksidan Setelah Dua Bulan Penyimpanan. Prosiding Seminar Nasional Teknologi Pangan

Nur, M. 2008. Belut si Ikan Lezat Bergizi Tinggi, Agromedia Pustaka. Jakarta

Palupi, N.S., Zakari, F.R., \& Prangdimurti, E. 2007. Pengaruh Pengolahan Terhadap nilai Gizi Pangan, Modul e-Learning ENBP, Departemen IImu \& Teknologi Pangan-Fateta-IPB Bogor.

Pane, F.A. 2006. Komposisi Asam Amino Daging Ayam Kampung, Broiler dan Produk Olahannya. Skripsi pada Teknologi Hasil Ternak Fak. Peternakan IPB-Bogor.

Prasetyawan, E.A. 2011. Uji kualitas minyak goreng pada para penjual gorengan di lingkungan kampus Universitas Jember. Thesis S1 pada Universitas Jember.
Pujiastuti, W. 2005. Pemilihan Bahan Kemasan Makanan. Makalah Pada Pelatihan Teknologi Pengemasan di Padang. BPPI Departemen Perindustrian RI.

Ruslan, R. 2007. Petunjuk Praktis Beternak Belut. Agromedia Pustaka, Jakarta

Sartika, R.A.D. 2009. Pengaruh Suhu dan Lama Proses Menggoreng (deep frying) Terhadap Pembentukan Asam Lemak Trans. http://journal.ui.ac.id/ upload/artikel. Diakses 22 November 2011.

Sundoro, S.R.M. 2002. Kiat Mengatasi Permasalahan Praktis Budidaya dan Pemanfaatan Belut, Agromedia Pustaka. Jakarta.

Sutarsi, Rahardjo, B., dan Hastuti, P. 2009. Divusivitas Air Pada Wortel Selama Penggorengan Hampa Udara, Jurnal Agritech Volume 29 No. 3 Tahun 2009.

Sutaryo. 2004. Penyimpanan dan Pengawetan Daging. Modul Materi Kuliah pada Fakultas Peternakan Universitas Diponegoro, Semarang. 